\title{
What clinical signs best identify severe illness in young infants aged $0-59$ days in developing countries? A systematic review
}

\author{
Newton Opiyo, ${ }^{1}$ Mike English ${ }^{1,2}$
}

${ }^{1} \mathrm{KEMRI} /$ Wellcome Trust Research Programme, Nairobi, Kenya

${ }^{2}$ Department of Paediatrics, University of Oxford, Oxford, UK

\section{Correspondence to} Newton Opiyo, KEMRI/ Wellcome Trust Research Programme, P.O. Box 43640, 00100 GPO, Nairobi, Kenya; nopiyo@

nairobi.kemri-wellcome.org

Accepted 3 November 2010 Published Online First 10 January 2011 online under the BMJ Journals unlocked scheme, see http:// adc.bmj.com/info/unlocked.dtl

\begin{abstract}
Despite recent overall improvement in the survival of under-five children worldwide, mortality among young infants remains high, and accounts for an increasing proportion of child deaths in resource-poor settings. In such settings, clinical decisions for appropriate management of severely ill infants have to be made on the basis of presenting clinical signs, and with limited or no laboratory facilities. This review summarises the evidence from observational studies of clinical signs of severe illnesses in young infants aged $0-59$ days, with a particular focus on defining a minimum set of best predictors of the need for hospital-level care. Available moderate to high quality evidence suggests that, among sick infants aged 0-59 days brought to a health facility, the following clinical signs_-alone or in combination — are likely to be the most valuable in identifying infants at risk of severe illness warranting hospital-level care: history of feeding difficulty, history of convulsions, temperature (axillary) $\geq 37.5^{\circ} \mathrm{C}$ or $<35.5^{\circ} \mathrm{C}$, change in level of activity, fast breathing/respiratory rate $\geq 60$ breaths per minute, severe chest indrawing, grunting and cyanosis.
\end{abstract}

\section{INTRODUCTION}

Despite recent overall improvement in the underfive mortality worldwide, young infant mortality remains a serious problem, accounting for an increasing proportion of child deaths in resourcepoor countries. ${ }^{1} 2$ Most young infant deaths continue to occur in homes with unwillingness, inability or delay in care seeking precluding appropriate referral of severely ill infants to adequately resourced health facilities. ${ }^{3}$ When healthcare is sought primary and even secondary health facilities (rural hospitals) in resource-poor countries often have no specialists (such as paediatricians) and limited or no laboratory diagnostic capability. ${ }^{4}$ In such settings, clinical decisions for appropriate management of severely ill infants have to be made on the basis of presenting clinical signs and symptoms alone. Typically health workers providing immediate care in these settings (even non-specialist physicians) have had as little as $2-3$ weeks instruction in the care of the sick newborn in basic training courses lasting 2-5 years.

So which clinical symptoms and signs are the most useful in such settings for identifying serious illness in this vulnerable group of patients? The current Kenyan adaptation of the World Health Organisation (WHO) Integrated Management of Childhood Illness (IMCI) algorithm recommends a panel of 15 clinical signs and symptoms for the identification of possible severe disease in infants aged $0-59$ days (ie, young infants). ${ }^{5}$ The current panel of signs was based on the WHO multicentre study of clinical features and causes of serious bacterial infections in young infants. ${ }^{6}$ Training health workers to identify large numbers of signs and then using an algorithm based on all these signs in often busy clinics in resource-poor settings may threaten feasibility of implementation. We therefore sought to summarise the evidence available on clinical predictors of serious illnesses to help define a likely minimum set of signs that would be most useful in revised Kenyan national guidelines for the hospital care component of IMCI named Emergency Triage, Assessment, and Treatment plus Admission Care $(\mathrm{ETAT}+)^{7} 8$ and potentially to broader child survival programs such as the WHO's IMCI approach.

The clinical question addressed was: In sick young infants aged $0-59$ days brought to a healthcare worker, which clinical signs, alone or in combination, are most useful at indicating the presence of severe disease warranting referral-level care or hospitalisation for interventions that might include: parenteral antibiotics, parenteral fluids, assisted feeding, oxygen therapy, etc.? In particular, our interest was to identify a minimum set of clinical features that might best: (1) predict the need for treatment of potentially severe infection; (2) usefully limit the number and variety of clinical indicators health workers must be aware of that would comprise a basic, minimum standard for knowledge, clinical assessment and management; (3) help identify ill young infants for more specialist review if this is available.

Our interest was not therefore to identify all the clinical symptoms and signs that may be associated with serious illness in those aged 0-59 days. Rather the emphasis is on those signs and symptoms which most efficiently and effectively identify young infants at risk of severe disease after excluding those with prematurity, very low birthweight or severe jaundice. We reasoned that such a minimum set of signs and symptoms should form the basis of practice, in managing possible neonatal sepsis in particular, for those with limited training or experience in young infant care if more specialist review is not available.

\section{METHODS}

\section{Search strategy and selection criteria}

Potential articles for inclusion were identified by direct searches of The Cochrane Library and MEDLINE (both from inception to November 2009). MEDLINE was searched via PubMed 
clinical query filters. The searches were performed by combining MeSH (Medical Subject Headings) terms that are indicative of acute illnesses of interest (sepsis, bacteraemia), predictive of illness severity (signs, symptoms, clinical predictors, clinical markers) and indicative of target age group (neonates, infants and children). Further published and unpublished papers were sought by screening through bibliographies of identified articles and writing to authors of identified relevant papers. No language or time limits were applied in the search strategy. The complete search strategy is available from the authors.

Studies were included if they reported a set of clinical signs predictive of severe illnesses or mortality in young infants aged $0-59$ days. Studies that included children aged 60 days and above were also considered if they also reported outcomes for children aged less than 60 days. Studies that examined a single disease state such as pneumonia or meningitis were not included in this review as arguably the clinical diagnosis of such specific diagnoses represents a more specialist task. Studies on bio-markers of severe illnesses (eg, C-reactive proteins) were excluded given the limited laboratory capability for their measurement in resource-poor settings. Studies conducted in high-income countries (as defined by the World Bank ${ }^{9}$ ) were excluded given the different spectrum and prevalence of severe illnesses. Only prospective studies with consecutive patient recruitments were considered. While a variety of definitions of 'severe illness episodes' have been suggested, in this paper severe illnesses were defined as cases warranting referral- or hospital-level care. Both community- and outpatient-based prospective observational studies were considered. Two reviewers independently screened through the titles and abstracts of identified articles, and applied the pre-defined selection criteria to assess their eligibility. Disagreements were resolved by discussion.

\section{Assessment of quality of evidence}

The strength of evidence-reflecting the appropriateness of the study design to answer the clinical question, the plausibility of prediction based on clinical signs, and the quality, quantity, and consistency of evidence-was independently assessed using the Grading of Recommendations Assessment, Development and Evaluation (GRADE) approach. ${ }^{10}$ The approach classifies the quality of evidence (ie, 'the extent to which one can be confident that an estimate of effect or association is correct') into four categories: high, moderate, low, or very low (table 1). The unique features of GRADE include: (1) explicit, comprehensive criteria for downgrading and upgrading quality of evidence ratings; (2) explicit evaluation of the importance of outcomes and (3) clear separation of quality of evidence from the strength of recommendations. The GRADE evidence profiles were prepared by one reviewer (NO) and verified independently by a second reviewer $(\mathrm{ME})$. Discrepancies in the quality ratings were resolved by discussion.

\section{RESULTS}

\section{Study characteristics}

Overall five ${ }^{4} \quad 6 \quad 11-13$ prospective observational studies ( $n=17506$ infants) out of 404 identified papers were included in this review (figure 1). All the included studies were conducted in resource-poor settings: three were based in outpatient clinics of first referral-level health facilities (basic or rural hospitals), ${ }^{6} 1213$ one was community-based ${ }^{11}$ while in another both outpatient and inpatient illness episodes were considered. ${ }^{4}$ Three studies ${ }^{4} 613$ evaluated clinical predictors of severe illnesses while the remaining two ${ }^{11}, 12$ reported risk factors for death. The mean duration of recruitment was 12 months. The characteristics of the included studies are summarised in table 2 .

In three studies, ${ }^{4} 613$ expert paediatrician opinion backed up with laboratory data (eg, blood or cerebrospinal fluid culture, chest radiography, pulse oximetry) was used as the diagnostic reference standard for severe illness classifications. There was however no 'gold standard' diagnostic reference in the remaining two studies, and the reported clinical signs were evaluated against a mortality outcome assessed by a neonatologist ${ }^{11}$ or from review of primary healthcare workers' 12 history taking and clinical examination. The quality of evidence for the suggested restricted set of best clinical predictors of severe illnesses was moderate to high (table 1).

\section{Deriving the panel of best clinical predictors}

A variety of statistical approaches were used in the individual reports reviewed to derive the best clinical predictors of severe illnesses and their combination (table 3). However, all used multivariable logistic regression models to adjust for known confounders (eg, place of study, age and weight) in attempts to improve the internal validity of the results. However, additional potential confounders and suppressers-such as differences in clinician practice, referral care patterns, prevalence of severe illnesses, HIV, patient case-mix, or temporal changes-were not adjusted for, and may further influence the performance of diagnostic algorithms in routine clinical settings. None of the derived sets of clinical signs reported in the studies identified has been the subject of further research to provide external validation or confirm effectiveness as has recently been recommended as appropriate for such an area of work. ${ }^{14}$

Comparability of individual study results is limited by the varied internal validation approaches used to develop the diagnostic algorithms: in three studies ${ }^{4} 613$ cross-validation was performed by re-calculating sensitivities and specificities (with 95\% CIs) following omission of signs, one at a time, from an existing set of independent clinical predictors. In another study, ${ }^{11}$ the performance of the derived set of 'any two of seven signs' (derivation set) was tested on a second 'postintervention' dataset (confirmatory set). The partial adjustment for potential confounders and the varied validation methods could increase the chances for observing heterogeneous sets of clinical signs. However, it should be noted that the two largest studies $^{6}{ }^{13}$ derived predictors from multi-country data and in one, ${ }^{13}$ country-specific results were also reported.

\section{Clinical predictors of severe illnesses or death}

Outlined below are results of the studies included that attempted to identify those signs that performed best, as a set, in terms of sensitivity and specificity (efficiency) for identifying severe neonatal and young infant illness.

In the largest ever study, a WHO multi-centre (Bangladesh, India, Pakistan, Bolivia, South Africa, Ghana) study ${ }^{13}$ on the clinical predictors of severe illnesses in children, 3177 neonates aged $0-6$ days and 5712 infants aged $7-59$ days brought with acute illnesses to health facilities were enrolled. Sepsis, pneumonia and meningitis were the most common diagnoses requiring hospital admission in both age groups, according to the gold-standard opinion, while those with severe jaundice were specifically excluded. A single algorithm (based on 
Table 1 GRADE summary combining quality of evidence and summary of findings*

Question: What clinical signs best identify severe illness in young infants aged $0-59$ days?

Settings: Primary healthcare settings in resource-poor settings

Diagnostic criteria: Clinical signs (clinical referral algorithms)

\begin{tabular}{|c|c|c|c|c|c|c|c|c|c|}
\hline \multicolumn{7}{|c|}{ Quality assessment } & \multicolumn{2}{|c|}{ Summary of findings } & \multirow[b]{2}{*}{ Importance } \\
\hline No of studies & No of infants & Design & Limitations & Inconsistency & Indirectness & Imprecision & $\begin{array}{l}\text { ORst } \\
\text { (Range) }\end{array}$ & $\begin{array}{l}\text { Quality } \\
\text { (GRADE) }\end{array}$ & \\
\hline \multicolumn{10}{|l|}{ Cyanosis ${ }^{\S}$} \\
\hline $3^{4613}$ & 13428 & $\begin{array}{l}\text { Observational } \\
\text { studies }\end{array}$ & $\begin{array}{l}\text { No serious } \\
\text { limitations }\end{array}$ & $\begin{array}{l}\text { No serious } \\
\text { inconsistency }\end{array}$ & $\begin{array}{l}\text { No serious } \\
\text { indirectness }\end{array}$ & $\begin{array}{l}\text { No serious } \\
\text { imprecision }\end{array}$ & $1.5-25.8$ & $\begin{array}{l}\oplus \oplus \oplus \oplus \\
\mathrm{HIGH}\end{array}$ & Critical \\
\hline \multicolumn{10}{|c|}{ Change in level of activity ${ }^{\ddagger}$} \\
\hline $3^{6} 1113$ & 15759 & $\begin{array}{l}\text { Observational } \\
\text { studies }\end{array}$ & $\begin{array}{l}\text { No serious } \\
\text { limitations }\end{array}$ & $\begin{array}{l}\text { No serious } \\
\text { inconsistency }\end{array}$ & $\begin{array}{l}\text { No serious } \\
\text { indirectness }\end{array}$ & $\begin{array}{l}\text { No serious } \\
\text { imprecision }\end{array}$ & $1.5-15.1$ & $\begin{array}{l}\oplus \oplus \oplus \oplus \\
\mathrm{HIGH}\end{array}$ & Critical \\
\hline \multicolumn{10}{|c|}{ Fast breathing (respiratory rate $\geq 60 \mathrm{bpm}$ ) } \\
\hline $3^{4613}$ & 13428 & $\begin{array}{l}\text { Observational } \\
\text { studies }\end{array}$ & $\begin{array}{l}\text { No serious } \\
\text { limitations }\end{array}$ & $\begin{array}{l}\text { No serious } \\
\text { inconsistency }\end{array}$ & $\begin{array}{l}\text { No serious } \\
\text { indirectness }\end{array}$ & $\begin{array}{l}\text { No serious } \\
\text { imprecision }\end{array}$ & $1.5-3.1$ & $\begin{array}{l}\oplus \oplus \oplus \ominus \\
\text { MODERATE }\end{array}$ & Critical \\
\hline \multicolumn{10}{|l|}{ Grunting } \\
\hline $2^{613}$ & 12192 & $\begin{array}{l}\text { Observational } \\
\text { studies }\end{array}$ & $\begin{array}{l}\text { No serious } \\
\text { limitations }\end{array}$ & $\begin{array}{l}\text { No serious } \\
\text { inconsistency }\end{array}$ & $\begin{array}{l}\text { No serious } \\
\text { indirectness }\end{array}$ & $\begin{array}{l}\text { No serious } \\
\text { imprecision }\end{array}$ & $1.5-2.9$ & $\begin{array}{l}\oplus \oplus \oplus \ominus \\
\text { MODERATE }\end{array}$ & Critical \\
\hline \multicolumn{10}{|c|}{ History of convulsions } \\
\hline $2^{613}$ & 12192 & $\begin{array}{l}\text { Observational } \\
\text { studies }\end{array}$ & $\begin{array}{l}\text { No serious } \\
\text { limitations }\end{array}$ & $\begin{array}{l}\text { No serious } \\
\text { inconsistency }\end{array}$ & $\begin{array}{l}\text { No serious } \\
\text { indirectness }\end{array}$ & $\begin{array}{l}\text { No serious } \\
\text { imprecision }\end{array}$ & $1.5-15.4$ & $\begin{array}{l}\oplus \oplus \oplus \oplus \\
\mathrm{HIGH}\end{array}$ & Critical \\
\hline \multicolumn{10}{|c|}{ History of difficulty feeding } \\
\hline $3^{4613}$ & 13428 & $\begin{array}{l}\text { Observational } \\
\text { studies }\end{array}$ & $\begin{array}{l}\text { No serious } \\
\text { limitations }\end{array}$ & $\begin{array}{l}\text { No serious } \\
\text { inconsistency }\end{array}$ & $\begin{array}{l}\text { No serious } \\
\text { indirectness }\end{array}$ & $\begin{array}{l}\text { No serious } \\
\text { imprecision }\end{array}$ & $1.5-10.0$ & $\begin{array}{l}\oplus \oplus \oplus \oplus \\
\mathrm{HIGH}\end{array}$ & Critical \\
\hline \multicolumn{10}{|c|}{ Severe chest indrawing } \\
\hline 4461213 & 13939 & $\begin{array}{l}\text { Observational } \\
\text { studies }\end{array}$ & $\begin{array}{l}\text { No serious } \\
\text { limitations }\end{array}$ & $\begin{array}{l}\text { No serious } \\
\text { inconsistency }\end{array}$ & $\begin{array}{l}\text { No serious } \\
\text { indirectness }\end{array}$ & $\begin{array}{l}\text { No serious } \\
\text { imprecision }\end{array}$ & $1.5-8.9$ & $\begin{array}{l}\oplus \oplus \oplus \ominus \\
\text { MODERATE }\end{array}$ & Critical \\
\hline \multicolumn{10}{|c|}{ Temperature (axillary) $\geq 37.5^{\circ} \mathrm{C}$ or $<35.5^{\circ} \mathrm{C}$} \\
\hline $3^{4613}$ & 13428 & $\begin{array}{l}\text { Observational } \\
\text { studies }\end{array}$ & $\begin{array}{l}\text { No serious } \\
\text { limitations }\end{array}$ & $\begin{array}{l}\text { No serious } \\
\text { inconsistency }\end{array}$ & $\begin{array}{l}\text { No serious } \\
\text { indirectness }\end{array}$ & $\begin{array}{l}\text { No serious } \\
\text { imprecision }\end{array}$ & $1.5-9.2$ & $\begin{array}{l}\oplus \oplus \oplus \oplus \\
\mathrm{HIGH}\end{array}$ & Critical \\
\hline
\end{tabular}

* Quality of evidence - the extent to which we can be confident that an estimate of effect or association is correct. The judgements are based on the: study design (randomised vs observational studies); likelihood of bias; consistency of the results across the studies; precision (wide or narrow Cls) of overall estimates and; directness of the evidence with respect to the populations, interventions and settings where the proposed intervention may be used

tORs of signs or symptoms calculated by multivariable analyses

${ }^{\ddagger}$ History of reduced activity, showing no spontaneous movement, stiff limbs, limps becoming limp

${ }^{\S}$ Bluish or greyish discoloration of the tongue

Quality of evidence is categorised as 'high', 'moderate', 'low' or 'very low'

- HIGH: Further research is very unlikely to change our confidence in the estimate of effect.

- MODERATE: Further research is likely to have an important impact on our confidence in the estimate of effect and may change the estimate.

- LOW: Further research is very likely to have an important impact on our confidence in the estimate of effect and is likely to change the estimate.

- VERY LOW: We are very uncertain about the estimate.

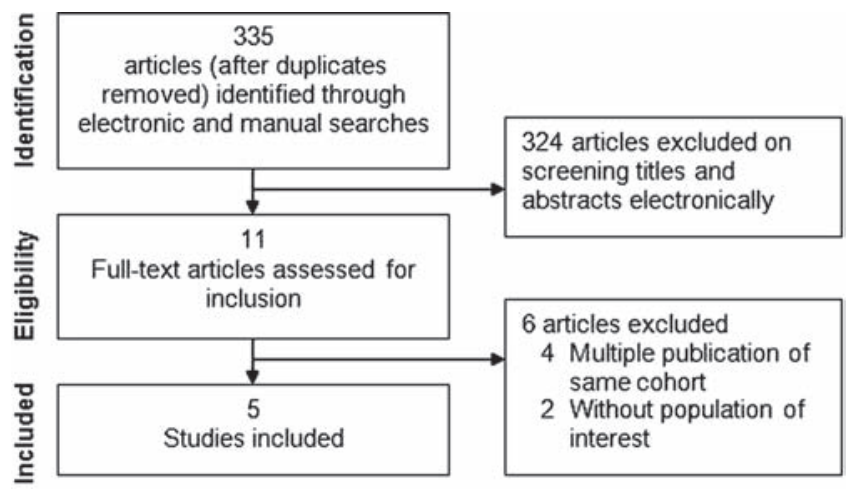

Figure 1 Flow diagram of the study selection process

the prevalence of any one sign or symptom) of seven signs-history of difficulty feeding, history of convulsions, movement only when stimulated, respiratory rate $\geq 60$ breaths per minute $(\mathrm{bpm})$, severe chest indrawing, temperature $\geq 37.5^{\circ} \mathrm{C}$ or $<35.5^{\circ} \mathrm{C}$ - had a sensitivity of $85 \%$ and a specificity of $75 \%$ in neonates aged $0-6$ days. The 7 signs also did relatively well in infants aged 7-59 days (sensitivity 74\%, specificity 75\%). The authors suggested that this referral decision algorithm could be used to predict the need for hospitalisation in all infants under 60 days of age who present to health facilities with acute illnesses.

In one Kenyan study ${ }^{4}$ of 1236 ill infants less than 60 days presenting to a rural district hospital, the presence of at least one of the following signs was $94 \%$ sensitive and $40 \%$ specific for severe disease (pneumonia, meningitis, prematurity, sepsis, acute respiratory infections, skin infections, purulent conjunctivitis) in infants aged 0-6 days: a history of feeding difficulty, breathing difficulty, cough or abnormal behaviour, fever or indrawing. In infants aged 7-59 days, the presence of at least one of the following signs was $97 \%$ sensitive and $56 \%$ specific for very severe disease: a history of feeding difficulty, abnormal behaviour, breathing difficulty, fast breathing or indrawing, cyanosis and a bulging fontanelle.

A re-analysis of an earlier WHO multicentre multi-country (Ethiopia, The Gambia, Papua New Guinea, The Philippines) study $^{6}$ ( $n=3303$ infants) found the following clinical signs to be significantly associated (sensitivity $87 \%$, specificity $54 \%$ ) with severe disease in young infants less than 60 days old presenting with bacterial infections (pneumonia, hypoxaemia, bacteraemia, meningitis) at hospitals or outpatient clinics: reduced feeding ability, no spontaneous movement, temperature $>38.0^{\circ} \mathrm{C}$, being drowsy or unconscious, a history of feeding problem 
Table 2 Characteristics of included studies

\begin{tabular}{|c|c|c|c|c|c|c|c|c|c|}
\hline Study & Design & Setting; Country & $\begin{array}{l}\text { Number of } \\
\text { infants }\end{array}$ & Age range & $\begin{array}{l}\text { Inclusion } \\
\text { criteria }\end{array}$ & Exclusion criteria & $\begin{array}{l}\text { Diagnostic } \\
\text { reference standard }\end{array}$ & $\begin{array}{l}\text { Common } \\
\text { diagnoses }\end{array}$ & Mortality/1000 \\
\hline YICSSG $^{13}$ & $\begin{array}{l}\text { Prospective, } \\
\text { consecutive }\end{array}$ & $\begin{array}{l}\text { Outpatient } \\
\text { Bangladesh, } \\
\text { India, } \\
\text { Pakistan, } \\
\text { Bolivia, } \\
\text { South Africa, } \\
\text { Ghana }\end{array}$ & $\begin{array}{l}0-6 \text { days: } \\
3177 \\
7-59 \text { days: } \\
5712\end{array}$ & $<60$ days & $\begin{array}{l}\text { Infants }<60 \text { days } \\
\text { brought to the } \\
\text { hospital or } \\
\text { outpatient clinic } \\
\text { with an } \\
\text { acute illness }\end{array}$ & $\begin{array}{l}\text { Well baby visits, } \\
\text { non-resident in study } \\
\text { area, previous } \\
\text { enrolment in study, } \\
\text { repeat episode of } \\
\text { same illness } \\
\text { Need for immediate } \\
\text { cardiopulmonary } \\
\text { resuscitation, } \\
\text { hospitalisation in the } \\
\text { previous } 2 \text { weeks } \\
\text { (except for delivery), } \\
\text { congenital } \\
\text { malformation }\end{array}$ & $\begin{array}{l}\text { Expert paediatrician } \\
\text { backed up with } \\
\text { laboratory data } \\
\text { (eg, blood, CSF, } \\
\text { chest radiography, } \\
\text { pulse oximetry) }\end{array}$ & $\begin{array}{l}\text { Sepsis, } \\
\text { Pneumonia, } \\
\text { Meningitis }\end{array}$ & $\begin{array}{l}0-6 \text { days: } \\
\text { Range: } 0-120 \\
7 \text { to } 60 \text { days: } \\
\text { Range: } 0-70\end{array}$ \\
\hline English et $a l^{4}$ & $\begin{array}{l}\text { Prospective, } \\
\text { consecutive }\end{array}$ & $\begin{array}{l}\text { Outpatient / } \\
\text { Inpatient } \\
\text { Kenya }\end{array}$ & 1236 & $<60$ days & $\begin{array}{l}\text { Hospital-based } \\
\text { birth cohort } \\
\text { weighing } \geq 1.5 \mathrm{~kg} \\
\text { All infants aged } \\
<90 \text { days } \\
\text { admitted to } \\
\text { hospital }\end{array}$ & Not reported & $\begin{array}{l}\text { Admitting doctor } \\
\text { backed up with } \\
\text { simple diagnostic } \\
\text { tests (full blood } \\
\text { count, blood culture, } \\
\text { lumbar puncture, } \\
\text { chest x-ray) }\end{array}$ & $\begin{array}{l}\text { Pneumonia, } \\
\text { Meningitis, } \\
\text { Prematurity, } \\
\text { Sepsis, } \\
\text { Acute } \\
\text { respiratory } \\
\text { infections, } \\
\text { Skin } \\
\text { infections, } \\
\text { Purulent } \\
\text { conjunctivitis }\end{array}$ & $\begin{array}{l}0-6 \text { days: } 320 \\
7-60 \text { days: } 70\end{array}$ \\
\hline Weber et $a /^{6}$ & $\begin{array}{l}\text { Prospective, } \\
\text { consecutive }\end{array}$ & $\begin{array}{l}\text { Hospitals or } \\
\text { outpatient clinics } \\
\text { Ethiopia, } \\
\text { The Gambia, } \\
\text { Papua New } \\
\text { Guinea, The } \\
\text { Philippines }\end{array}$ & 3303 & $<60$ days & $\begin{array}{l}\text { Infants }<91 \text { days } \\
\text { with possible } \\
\text { acute infections }\end{array}$ & $\begin{array}{l}\text { Infants with } \\
\text { congenital heart } \\
\text { disease and } \\
\text { hypoxemia }\end{array}$ & $\begin{array}{l}\text { Expert paediatrician } \\
\text { backed up with } \\
\text { laboratory data (eg, } \\
\text { blood culture, chest } \\
\text { radiograph, lumbar } \\
\text { puncture, pulse } \\
\text { oximetry) }\end{array}$ & $\begin{array}{l}\text { Pneumonia, } \\
\text { Hypoxaemia, } \\
\text { Bacteremia, } \\
\text { Meningitis }\end{array}$ & $0-59$ days: 59 \\
\hline Dukeet $a l^{12}$ & $\begin{array}{l}\text { Prospective, } \\
\text { consecutive }\end{array}$ & $\begin{array}{l}\text { Outpatient clinic } \\
\text { Papua New } \\
\text { Guinea }\end{array}$ & 511 & $<60$ days & $\begin{array}{l}\text { All sick young } \\
\text { infants presenting } \\
\text { to rural health } \\
\text { centres }\end{array}$ & Not reported & $\begin{array}{l}\text { Mortality } \\
\text { outcome following } \\
\text { a review of primary } \\
\text { healthcare workers' } \\
\text { history taking and } \\
\text { clinical examination }\end{array}$ & $\begin{array}{l}\text { Neonatal } \\
\text { sepsis, } \\
\text { Pneumonia, } \\
\text { Malaria }\end{array}$ & $\begin{array}{l}0-59 \text { days: } \\
59.8\end{array}$ \\
\hline Banget al ${ }^{11}$ & $\begin{array}{l}\text { Prospective, } \\
\text { consecutive }\end{array}$ & $\begin{array}{l}\text { Community } \\
\text { India }\end{array}$ & 3567 & $<28$ days & $\begin{array}{l}\text { All neonates } \\
\text { born in study } \\
\text { villages }\end{array}$ & Not reported & $\begin{array}{l}\text { Mortality outcome } \\
\text { judged by a } \\
\text { neonatologist as due } \\
\text { to sepsis }\end{array}$ & $\begin{array}{l}\text { 'Sepsis' } \\
\text { (defined } \\
\text { as sepsis, } \\
\text { meningitis, } \\
\text { pneumonia) }\end{array}$ & $0-28$ days: 51.2 \\
\hline
\end{tabular}

CSF, cerebrospinal fluid, YICSSG, Young Infants Clinical Signs Study Group.

or change in activity, agitation, lower chest wall indrawing, respiratory rate $>60$ bpm, grunting, cyanosis, convulsions, bulging fontanelle and slow digital capillary refill.

In one multi-site (single country) study ${ }^{12}$ of 511 infants less than 60 days of age presenting to rural health centres in Papua New Guinea, the following signs were associated with an increased risk of death: inability to feed, fast respiratory rate (fast breathing), apnea, cyanosis, 'too small', 'skin-cold' and severe abdominal distension. The most common diagnoses included neonatal sepsis, pneumonia and malaria. The authors concluded that the above signs could be used as triggers for emergency care, longer observation or urgent referral.

Finally, in one field study ${ }^{11}$ of 3567 neonates aged less than 28 days in India, simultaneous presence of any two of the following seven clinical signs predicted death from sepsis with a $100 \%$ sensitivity and $92 \%$ specificity: reduced or stopped sucking, weak or no cry, limbs becoming limp, vomiting or abdominal distension, baby cold to touch, severe chest indrawing and umbilical infection. The authors concluded that these criteria can be used by health workers to select sick neonates for treatment or referral.

Taken together, and based on the overlap of study results and the consistency of performance of clinical symptoms and signs in identifying severe illness, moderate to high quality evidence (table 1 and 4) suggest that the following eight clinical signs-based on their strengths of associations (ORs) with severe illnesses, prevalence in the enrolled infants in the primary studies, and ease of clinical recognition-are likely to be the most valuable in predicting severe illnesses in young infants presenting at primary healthcare facilities: history of feeding difficulty, history of convulsions, temperature (axillary) $\geq 37.5^{\circ} \mathrm{C}$ or $<35.5^{\circ} \mathrm{C}$, change in level of activity, fast breathing/respiratory rate $\geq 60 \mathrm{bpm}$, severe chest indrawing, grunting and cyanosis. A suggested more sensitive alternative to cyanosis, and which has been shown to be strongly associated with mortality would be hypoxaemia-economically and reliably diagnosed using pulse oximetry. ${ }^{15} 16$

\section{DISCUSSION}

\section{Interpretation of findings}

This review set out to define a set of simple best clinical predictors of severe illnesses in infants aged $0-59$ days. The limited set of clinical signs for which extensive evidence supporting their value exists were reported to have high sensitivity (indicating that they were less likely to miss severe illness 
Table 3 Deriving best clinical predictors of severe illnesses

\begin{tabular}{|c|c|}
\hline Study & Analytical strategy \\
\hline ang et $a l^{11}$ & $\begin{array}{l}\text { The sensitivity and specificity of } 16 \text { signs significantly associated with sepsis death (lower } 95 \% \mathrm{Cl} \text { of } 0 \text { Rs }>1 \text { were calculated to identify a prediction } \\
\text { rule of any two of a set of six signs. } \\
\text { The best set of 'any two of seven criteria' ( } 100 \% \text { sensitivity, } 92 \% \text { specificity) was subsequently selected by sequentially adding signs of the respiratory } \\
\text { system*, one at a time, to previously selected six signs. }\end{array}$ \\
\hline uke et $a^{12}$ & $\begin{array}{l}\text { Clinical signs associated with death were identified using univariate logistic regression } 0 R s(<0.05) \text {. } \\
\text { A panel of four independent clinical predictors of death (ORs } 3.6 \text { to } 6.2) \text { was identified by multivariate logistic regression analyses using independent } \\
\text { predictors that were present in one third or more of the deaths. }\end{array}$ \\
\hline English et $a l^{4}$ & $\begin{array}{l}\text { Signs significantly associated with very severe illness were identified by univariate } 0 R \text { s }- \text { calculated using logistic regression that took account of likely } \\
\text { collinearity } \dagger \text { between signs. } \\
\text { Panel of best clinical predictors ( } 0-6 \text { days: } 94 \% \text { sensitivity, } 40 \% \text { specificity; } 7-59 \text { days: } 97 \% \text { sensitivity, } 56 \% \text { specificity) was subsequently derived by } \\
\text { subjecting the identified independent predictors to multiple multivariate logistic regressions. }\end{array}$ \\
\hline Weber et $a l^{6}$ & $\begin{array}{l}\text { A set of independent predictors (ORs }>2.5) \text { identified (by univariate logistic regression analyses) from an expert selected panel of candidate signs. } \\
\text { The final set of best clinical predictors }(87 \% \text { sensitivity, } 54 \% \text { specificity) was subsequently derived from multivariate analyses of several combinations } \\
\text { of independent predictors of severe illnesses. }\end{array}$ \\
\hline YICSSG ${ }^{13}$ & $\begin{array}{l}\text { A panel of } 12 \text { independent clinical predictors of the need for urgent hospital care was identified by univariate logistic regressions. } \\
\text { A further reduction of the list to seven signs }(0 R s \text { s.7-15.4, } p<0.05) \text { was made on the basis of low prevalence of some signs and negligible change in } \\
\text { sensitivity (calculated by random-effects meta-analysis }{ }^{\ddagger} \text { ) if they were omitted. }\end{array}$ \\
\hline
\end{tabular}

* Respiratory rate $\geq 60$ breaths per minute, chest indrawing and grunting

†Signs with similar ORs

${ }^{\ddagger}$ Weights studies more equally/yields more conservative estimates

YICSSG, Young Infants Clinical Signs Study Group.

episodes) and reasonable specificity (indicating that they were likely to reduce unnecessary hospitalisation or referral). These symptoms and signs were supported by data from large prospective observational studies conducted in resource-limited healthcare settings. Such settings are likely to reflect typical busy clinical situations in many resource-poor country health facilities with limited laboratory diagnostic facilities and high health worker workloads.

The eight identified symptoms and signs-history of feeding difficulty, history of convulsions, temperature (axillary) $\geq 37.5^{\circ} \mathrm{C}$ or $<35.5^{\circ} \mathrm{C}$, change in level of activity, fast breathing/ respiratory rate $\geq 60 \mathrm{bpm}$, severe chest indrawing, grunting and cyanosis - are therefore probably the most appropriate to employ as a basic, minimum standard for knowledge, clinical assessment and management for health workers with limited training or experience in the care of sick newborns or young infants working in rural primary healthcare settings or emergency outpatient clinics of district hospitals in resource-poor countries. Presence of any one of these danger signs should prompt health workers with only basic training to initiate treatment for serious illness until an early opinion or review is available from a health worker with a higher level of training or experience.

Such an approach prioritises sensitivity (not missing a true serious illness) at the expense of specificity (restricting treatment of those without serious illness) in a population of vulnerable patients. Thus, it should be remembered that the presence of any one of the clinical danger signs does not provide a reliable clinical diagnosis but rather a reasonable basis for initiating empiric treatment. Such an approach is justified given the high mortality in the neonatal period (which has been documented to be $40 \%$ of all under-five child deaths globally, with $99 \%$ in resource-poor countries ${ }^{1}$ ) and the limited training and skills of qualified health workers with only basic training who comprise the majority of those caring for patients even at hospital levels. It should however be remembered that these referral/empiric treatment criteria are not necessarily applicable to illness episodes for presentations with the primary problems of jaundice (since severity would depend on the level of hyperbilirubinemia), birth asphyxia or prematurity.
The focus of this review was specifically on identifying a minimum set of signs and symptoms that health workers should be able to identify with the goal of efficiently initiating empiric treatment or specialist referral. Clinical features that do not necessarily improve the sensitivity and specificity of this set may nonetheless be strongly associated with the outcome of serious illness (table 5). Although studies varied in the range of signs and symptoms examined, in univariate analyses, at least two studies indicated strong associations between serious illness and signs that are perhaps worthy of further evaluation. Pallor, slow capillary refilling and a bulging fontanelle may be indicative of either specific but uncommon pathologies and/or the need for specific interventions that go beyond standard empiric antibiotics, provision of oxygen and feeding support.

In this review, the use of the GRADE approach added scientific rigor to the process of compiling and rating the quality of evidence. Our experience suggests that it is feasible to use GRADE even for evaluations of diagnostic/screening interventions. However, a number of challenges remain, particularly regarding assessment of the: (1) range of baseline (control) risks (a useful measure of the typical burden of outcomes)-as these remain largely under-reported in diagnostic observational studies and; (2) likelihood of publication (reporting) bias given the heterogeneous reporting of diagnostic outcome data.

\section{Limitations of summarised evidence}

First, a limited number of well-conducted studies ( $N=5$ ) were available for inclusion in this review and the heterogeneous nature of available outcome data made it impossible to statistically assess the influence of publication bias on the results. However, the five studies enrolled (consecutively) a large number of infants ( $N=17506)$, and the current results would therefore be expected to be robust to inclusions of any un-retrieved eligible published or unpublished studies. Second, the main aim of clinical algorithms is to identify severe illness so that appropriate treatment is initiated promptly; clinical predictors of death (reported in two studies) may therefore be of limited value-as they indicate advanced stages of disease during which treatment may be less likely to work. Finally, the lack of prospective studies 
Table 4 Independent clinical predictors of severe illness in young infants*

\begin{tabular}{|c|c|c|c|c|c|c|c|}
\hline & Bang et $a l^{11}$ & Duke et $a l^{\dagger 12}$ & English et $a l^{4}$ & English et $a l^{4}$ & Weber et $a^{6}$ & YICSSG $^{ \pm 13}$ & \\
\hline & $0-28$ days & 0-59 days & 0-6 days & 7-59 days & $0-60$ days & $0-6$ days & ORs (range) \\
\hline \multicolumn{8}{|l|}{ Feeding } \\
\hline History of difficult feeding & - & - & $7.3(3.1-16.8)$ & $2.8(2.6-5.0)$ & $>1.5$ & $10.0(6.9-14.5)$ & $1.5-10.0$ \\
\hline Reduced feeding ability & - & SP & - & - & $>1.5$ & - & $1.5-7.4$ \\
\hline Sucking weak, reduced or stopped & $7.9(1.8-34.2)$ & - & - & - & - & - & 7.9 \\
\hline \multicolumn{8}{|l|}{ Activity } \\
\hline History of change in level of activity & - & - & - & - & $>1.5$ & - & 1.5 \\
\hline Lethargy & - & - & - & - & - & $3.5(1.7-7.1)$ & 3.5 \\
\hline Limps becoming limp & $3.3(0.9-12.0)$ & - & - & - & - & - & 3.3 \\
\hline Movement only when stimulated & - & - & - & - & - & $6.9(3.0-15.5)$ & 6.9 \\
\hline No spontaneous movement & - & - & - & - & $>1.5$ & - & 1.5 \\
\hline Stiff limbs & - & - & - & - & - & $15.1(2.2-105.9)$ & 15.1 \\
\hline \multicolumn{8}{|l|}{ Respiratory } \\
\hline Apnea & - & $4.2(1.1-15.4)$ & - & - & - & - & 4.2 \\
\hline Cough & & - & $0.1(0.02-0.5)$ & & - & & 0.1 \\
\hline Difficulty breathing & - & - & $2.1(1.0-2.6)$ & $1.8(0.9-3.5)$ & - & - & $1.8-2.1$ \\
\hline Fast breathing & - & - & - & $3.1(1.8-5.3)$ & - & - & 3.1 \\
\hline Grunting & - & - & - & - & $>1.5$ & $2.9(1.1-7.5)$ & $1.5-2.9$ \\
\hline Severe (deep) lower chest indrawing & - & $3.6(0.94-13.9)$ & $3.0(1.1-8.2)$ & $2.4(1.3-4.7)$ & $>1.5$ & $8.9(4.0-20.1)$ & $1.5-8.9$ \\
\hline Respiratory rate $\geq 60$ breaths per minute & - & - & - & - & $>1.5$ & $2.7(1.9-3.8)$ & $1.5-2.7$ \\
\hline \multicolumn{8}{|l|}{ Skin } \\
\hline Cyanosis & - & - & - & $25.8(1.9-354)$ & $>1.5$ & $13.7(1.6-116.5)$ & $1.5-13.7$ \\
\hline Prolonged capillary refill & - & - & - & - & $>1.5$ & $10.5(5.1-21.7)$ & $1.5-10.5$ \\
\hline 'Skin cold' ('baby cold to touch') & $3.5(1.0-12.4)$ & $6.2(1.5-26.6)$ & - & - & - & - & $3.5-6.2$ \\
\hline Temperature $<35.5^{\circ} \mathrm{C}$ & - & - & - & - & - & $9.2(4.6-18.6)$ & 9.2 \\
\hline Temperature (axillary) $\geq 37.5^{\circ} \mathrm{C}$ & - & - & $3.2(1.7-6.3)$ & - & $>1.5$ & $3.4(2.4-4.9)$ & $1.5-3.4$ \\
\hline \multicolumn{8}{|l|}{ Conscious state } \\
\hline Conscious state agitated & - & - & - & - & $>1.5$ & - & 1.5 \\
\hline Unconscious or drowsy & - & - & - & - & $>1.5$ & - & 1.5 \\
\hline \multicolumn{8}{|l|}{ Others } \\
\hline Abnormal behaviour & - & - & $2.4(1.2-4.6)$ & $3.1(1.7-5.6)$ & - & - & $2.4-3.1$ \\
\hline Bulging fontanelle & - & - & - & $1.9(3.0-39.9)$ & $>1.5$ & - & $1.5-1.9$ \\
\hline Cry abnormal, weak, or stopped & $14.3(3.9-52.1)$ & - & - & - & - & - & 14.3 \\
\hline History of convulsions & - & - & - & - & $>1.5$ & $15.4(6.4-37.2)$ & 15.4 \\
\hline Severe abdominal distension / vomiting & $6.8(1.7-27.2)$ & - & - & - & - & - & 6.8 \\
\hline
\end{tabular}

OR not reported; $(p<0.001)$

*Values are multivariate ORs with $95 \%$ Cls

${ }^{\dagger}$ Studies reporting predictors (risk factors) for death

${ }^{\ddagger}$ Panel of best clinical predictors had comparable sensitivities and specificities in 0-6 days and 7-59 days age groups

SP, significant predictor; YICSSG, Young Infants Clinical Signs Study Group.

confirming clinical effectiveness of the referral algorithms after implementation has also previously been noted.

In our narrative summary of study findings variation in the strengths of association (ORs) of specific signs and symptoms and serious illness was apparent. A possible explanation for the differences in the magnitude of ORs could be differences in the spectrum (case-mix or co-morbidities) and prevalence of illness episodes-for example, studies may vary in the proportion of cases that are meningitis or include a larger subset of severely ill infants (manifest as a higher death rate). Where populations studied vary, likelihood ratios $^{17}$ — which are more robust to changes in disease prevalence compared to sensitivity and specificity, and that were computed in only 1 study 6 might have yielded more rigorous estimates of the association of clinical signs with severe illnesses. Another possible explanation for the differences in the ORs could be differences in the 'gold standard' criteria for verification of severe illness (ie, likelihood of 'reference standard misclassification')—for example, clinical signs such as cyanosis may be detected and interpreted more accurately in studies where the reference standard was an experienced neonatologist assisted by pulse oximetry. These factors may explain the relatively higher ORs reported in the largest multi-centre study. ${ }^{13}$

None of the included studies considered the cost-benefit implications of reported clinical referral algorithms compared to alternative diagnostic strategies-such as illness severity scoring algorithms (eg, the Baby $\mathrm{Check}^{18}$ ) or rapid point-ofcare laboratory bio-markers of illness severity (eg, C-reactive proteins ${ }^{19}$ ). However, use of the minimum subset of signs and symptoms represents a refinement of the currently larger set of fifteen signs recommended in Kenyan IMCI guidelines (table 6$)^{5}$ and might be expected to be implemented more easily and efficiently. The suggested panel of eight signs of severe illness includes all the six signs recommended in the revised WHO IMCI guidelines (table 6). ${ }^{20}$

\section{Implications for practice and policy}

The set of diagnostic features proposed as a basic algorithm for initiating referral/empiric treatment should be feasible to implement as part of revised IMCI strategy including those 
aimed at first referral level facilities staffed by health workers with only basic training. To promote adherence and improve the diagnostic value of the algorithm, we suggest: (1) concurrent implementation and scaling up of community-based intervention strategies aimed at improving early healthcare seeking behaviour for any of the suggested best predictors of severe illnesses, for example, through danger-signs sensitisation- health education for families ${ }^{19}$ and; (2) preservice and inservice (refresher) training for health workers on recognition and interpretation of the suggested danger signs (given their subtle nature of presentation and the low prevalence of severe young infant illnesses). Such measures should ideally be linked to efforts to improve empiric treatment, supportive care and access to healthcare providers with higher levels of training.

Table 5 Significant predictors* of severe illnesses in univariate analyses

\begin{tabular}{|c|c|c|c|c|c|c|c|}
\hline & Bang et $a l^{11}$ & Duke et $a l^{t 12}$ & English et $a I^{4}$ & English et $a l^{4}$ & Weber et $a^{6}$ & YICSSG $2008^{\ddagger 13}$ & YICSSG $2008^{\ddagger 13}$ \\
\hline & $0-28$ days & $0-59$ days & $0-6$ days & $7-59$ days & $0-60$ days & 0-6 days & \\
\hline Abdominal distension & - & - & - & - & - & $4.6(2.2-9.7)$ & - \\
\hline Abnormal movements & - & - & $4.5(2.6-7.6)$ & $3.3(2.0-5.6)$ & - & - & - \\
\hline Bulging fontanelle & - & $18.7(2.5-141.8)$ & $2.8(0.3-32.0)$ & - & - & $5.6(1.8-18.0)$ & $9.6(3.1-29.9)$ \\
\hline Chest indrawing & - & $3.7(1.4-9.9)$ & - & - & - & - & - \\
\hline $\begin{array}{l}\text { Consolability: continues to } \\
\text { cry/fuss }\end{array}$ & - & - & - & - & 2.9 to $4.0^{\ddagger}$ & - & - \\
\hline Cyanosis & - & - & $2.4(1.0-5.6)$ & - & - & $35.0(10.0-122.7)$ & $7.1(2.5-20.3)$ \\
\hline Drowsy / unconscious & $40.2(14.0-116.6)$ & - & - & - & - & - & \\
\hline Grunting & $7.0(2.6-18.7)$ & - & - & $2.4(1.3-4.8)$ & - & $12.6(4.1-38.7)$ & $9.7(5.4-17.4)$ \\
\hline History of blood in stool & - & - & - & - & - & - & $6.1(2.2-16.9)$ \\
\hline History of change in crying & - & - & - & - & $1.9(1.4-2.7)$ & - & - \\
\hline History of cough & - & - & - & - & $1.5(1.1-2.0)$ & - & - \\
\hline History of diarrhoea & - & - & - & - & - & - & $1.5(1.1-2.2)$ \\
\hline History of fever & - & - & - & - & - & $2.4(1.8-3.2)$ & $2.9(2.3-3.7)$ \\
\hline History of no cry at birth & - & - & - & - & - & $2.6(1.3-5.4)$ & - \\
\hline Hypothermia $^{\dagger}$ & - & $5.3(1.5-18.8)$ & - & - & - & - & - \\
\hline Lethargic & - & - & $3.1(1.8-5.3)$ & $2.6(1.5-4.3)$ & - & $20.5(13.8-30.5)$ & $24.0(15.6-36.9)$ \\
\hline Nasal flaring & - & - & $2.2(1.0-4.9)$ & $3.0(1.9-4.8)$ & - & $15.7(5.7-43.1)$ & $14.8(7.8-28.2)$ \\
\hline Pallor & - & $37.5(3.2-436.8)$ & $2.8(0.3-31.8)$ & $16.4(3.4-78.0)$ & - & & \\
\hline Prolonged capillary refill & - & - & - & - & - & $12.1(5.2-28.3)$ & $31.6(11.8-84.3)$ \\
\hline Reduced skin turgor & - & - & - & - & - & $3.7(2.2-6.2)$ & $15.7(6.6-37.4)$ \\
\hline Restless and irritable & - & - & - & - & - & $7.2(2.4-21.3)$ & $13.9(6.8-28.3)$ \\
\hline Stiff limbs & - & - & - & - & - & $44.9(10.7-188.2)$ & $7.8(2.1-29.2)$ \\
\hline Sunken eyes & - & - & - & - & - & - & $11.5(3.7-35.6)$ \\
\hline Temperature (axillary) $35.0^{\circ} \mathrm{C}$ & $11.5(4.5-30.0)$ & - & - & - & - & - & - \\
\hline Unconscious & - & - & $5.0(1.7-14.3)$ & $3.9(1.6-9.6)$ & - & - & - \\
\hline
\end{tabular}

${ }^{*}$ Signs significantly associated with severe illnesses ( $p$ values $<0.05$ ) not included in final multivariable models; Numbers are univariate 0 Rs with $95 \%$ Cls ${ }^{\dagger}$ Axillary temperature $<36.0^{\circ} \mathrm{C}$

${ }^{\ddagger}$ Range of ORs for association with severe disease (sepsis, meningitis or hypoxemia)

YICSSG - Young Infants Clinical Signs Study Group.

Table 6 Comparison of current Kenyan IMCI referral criteria, revised WHO criteria and proposed criteria based on studies included in this review

\begin{tabular}{|c|c|c|}
\hline Current Kenyan IMCI referral criteria ${ }^{5}$ & Revised WHO IMCI referral criteria ${ }^{20}$ & $\begin{array}{l}\text { Proposed referral criteria based on studies included } \\
\text { in this review } 4,6,11-13\end{array}$ \\
\hline Not able to feed or breastfeed & Not feeding well & History of feeding difficulty \\
\hline Convulsions or convulsing now & Convulsions & History of convulsions \\
\hline Fast breathing ( $60 \mathrm{bpm}$ or more) & Fast breathing (60 bpm or more) & Fast breathing (respiratory rate $\geq 60$ bpm) \\
\hline Severe chest indrawing & Severe chest indrawing & Severe chest indrawing \\
\hline $\begin{array}{l}\text { Fever }\left(\geq 37.5^{\circ} \mathrm{C}^{*} \text { or feels hot }\right) \text { or low body temperature } \\
\left(<35.5^{\circ} \mathrm{C}^{*} \text { or feels cold }\right)\end{array}$ & Fever $\left(\geq 37.5^{\circ} \mathrm{C}^{*}\right)$ or low body temperature $\left(<35.5^{\circ} \mathrm{C}^{*}\right)$ & Temperature (axillary) $\geq 37.5^{\circ} \mathrm{C}$ or $<35.5^{\circ} \mathrm{C}$ \\
\hline No movements even when stimulated & Movement only when stimulated or no movement at all & Change in level of activity \\
\hline Grunting or wheezing & - & Grunting \\
\hline Central cyanosis & - & Cyanosis \\
\hline Gasping & - & - \\
\hline Not breathing at all even when stimulated & - & - \\
\hline Respiratory rate less than $20 \mathrm{bpm}$ & - & - \\
\hline Nasal flaring & & - \\
\hline Bulging fontanelle & - & - \\
\hline Pus draining from the ear & - & - \\
\hline Drowsy (lethargic) or unconscious & - & - \\
\hline
\end{tabular}

Proposed referral criteria based on studies included in this review ${ }^{4,6,11-13}$

\footnotetext{
${ }^{*}$ Axillary temperature

bpm, breaths per minute.
} 


\section{Implications for future research}

The findings of this review have a number of important implications for future research. First, we suggest further large observational validation studies to confirm the effectiveness of the proposed minimum set of eight clinical signs and symptoms in routine practice. Second, we suggest research should examine the approach's diagnostic performance among HIV-infected infants. ${ }^{21}$ Finally, improvements to this clinical approach, possibly by combining it with bio-markers of severe illness, should be examined.

\section{CONCLUSION}

The findings of this review suggest that, among sick infants aged $0-59$ days, brought to a healthcare worker with only basic training, the following clinical signs-alone or in combination-indicate severe illness warranting referral or hospitalisation and empiric treatment in the absence of a senior opinion: history of feeding difficulty, history of convulsions, temperature (axillary) $\geq 37.5^{\circ} \mathrm{C}$ or $<35.5^{\circ} \mathrm{C}$, change in level of activity, fast breathing/respiratory rate $\geq 60 \mathrm{bpm}$, severe chest indrawing, grunting, and cyanosis. Focusing only on health worker triaging skills without addressing the barriers to healthcare seeking may limit the impact on mortality of the referral algorithm-hence the need for concurrent implementation of interventions to improve care-seeking.

Acknowledgements This manuscript is published with the permission of the Director of KEMRI.

Funding Mike English is funded by a Wellcome Trust Senior Fellowship (\#076827) and Newton Opiyo is supported by funding from a Wellcome Trust Strategic Award (\#084538).

\section{Competing interests None.}

Contributors ME conceived the idea for the review. NO and ME screened records for eligibility, assessed quality of included studies and interpreted findings. NO prepared the first draft of the review.

Provenance and peer review Not commissioned; externally peer reviewed.

\section{REFERENCES}

1. Central Bureau of Statistics and Ministry of Planning and National Development. Kenya Demographic and Health Survey - Preliminary Report. Nairobi: Government of Kenya, 2008.
2. Joy L, Kate K. Opportunities for Africa's Newborns. Practical Data, Policy and Programmatic Support for Newborn Care in Africa. Geneva, Switzerland: The Partnership for Maternal, Newborn and Child Health 2006.

3. World Health Organisation. The World Health Report 2005: Make Every Mother and Child Count. Geneva, Switzerland: WHO, 2005.

4. English M, Ngama M, Mwalekwa L, et al. Signs of illness in Kenyan infants aged less than 60 days. Bull World Health Organ 2004;82:323-9.

5. Ministry of Health. Integrated Management of Childhood IIIness. Kenya: Ministry of Health, 2008.

6. Weber M, Carlin J, Gatchalian S, et al. Predictors of neonatal sepsis in developing countries. Pediatr Infect Dis J 2003;22:711-16.

7. Irimu G, Wamae A, Wasunna A, et al. Developing and introducing evidence based clinical practice guidelines for serious illness in Kenya. Arch Dis Child 2008:93:799-804.

8. Ministry of Medical Services. Basic Paediatric Protocols - Revised. Kenya: Government of Kenya, 2010.

9. World Bank 2006. Data and Statistics, World Bank. http://web.worldbank.org/ (accessed 4 December 2009).

10. Schünemann H, Oxman AD, Brozek J, et al. GRADE Working Group. Grading quality of evidence and strength of recommendations for diagnostic tests and strategies. BMJ 2008; 336:1106-10.

11. Bang AT, Bang RA, Reddy $M H$, et al. Simple clinical criteria to identify sepsis or pneumonia in neonates in the community needing treatment or referral. Pediatr Infect Dis J 2005;24:335-41.

12. Duke T, Oa O, Mokela D, et al. The management of sick young infants at primary health centres in a rural developing country. Arch Dis Child 2005;90:200-5.

13. Young Infants Clinical Signs Study Group. Clinical signs that predict severe illness in children under age 2 months: a multicentre study. Lancet 2008;371:97-8.

14. Altman DG, Vergouwe $Y$, Royston $P$, et al. Prognosis and prognostic research validating a prognostic model. BMJ 2009;338:b605.

15. Mwaniki MK, Nokes DJ, Ignas J, et al. Emergency triage assessment for hypoxaemia in neonates and young children in a Kenyan hospital: an observational study. Bull World Health Organ 2009;87:263-70.

16. Subhi R, Adamson M, Campbell H, et al. The prevalence of hypoxaemia among ill children in developing countries: a systematic review. Lancet Infect Dis 2009:9:219-27.

17. Centre for Evidence-Based Medicine. Likelihood ratios. http://www.cebm.net/ index.aspx?0=1043 (accessed 18 January 2010)

18. Morley CJ, Rashiq H, Thomas IR, et al. Use of Baby Check to assess the severity of illness in babies attending a clinic in The Gambia. J Trop Pediatr 1994:40:144-8.

19. Bazzano AN, Kirkwood BR, Tawiah-Agyemang C, et al. Beyond symptom recognition: care-seeking for ill newborns in rural Ghana. Trop Med Int Health 2008; 13:123-8.

20. WHO IMCI chart booklet. http://www.who.int/child adolescent health/ documents/IMCI chartbooklet/en/ (accessed 12 October 2010).

21. Carrol E, Mankhambo LA, Jeffers G, et al. The diagnostic and prognostic accuracy of five markers of serious bacterial infection in Malawian children with signs of severe infection. PLoS One 2009:4:e6621. 